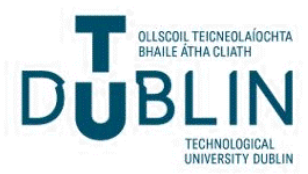

Technological University Dublin

ARROW@TU Dublin

\section{Evaluation of chemical immersion treatments to reduce microbial populations in fresh beef}

\author{
Ahmed Kassem \\ University College Dublin, ahmed.hushimat@ucdconnect.ie \\ Joseph Meade \\ University College Dublin \\ James Gibbons \\ University College Dublin
}

See next page for additional authors

Follow this and additional works at: https://arrow.tudublin.ie/schfsehart

Part of the Biology Commons, Chemistry Commons, Food Science Commons, and the Medicine and Health Sciences Commons

\section{Recommended Citation}

Kassem A, Meade J, Gibbons J, McGill K, Walsh C, Lyng J, Whyte P. Evaluation of chemical immersion treatments to reduce microbial populations in fresh beef. Int J Food Microbiol. 2017 Nov 16;261:19-24. doi: 10.1016/j.ijfoodmicro.2017.08.005. Epub 2017 Sep 5. PMID: 28889054.

This Article is brought to you for free and open access by the School of Food Science and Environmental Health at ARROW@TU Dublin. It has been accepted for inclusion in Articles by an authorized administrator of ARROW@TU Dublin. For more information, please contact arrow.admin@tudublin.ie, aisling.coyne@tudublin.ie, gerard.connolly@tudublin.ie.

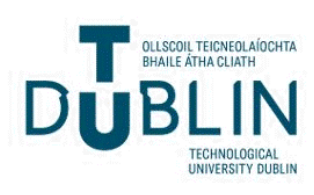




\section{Authors}

Ahmed Kassem, Joseph Meade, James Gibbons, Kevina McGill, Ciara Walsh, James Lyng, and Paul Whyte 


\title{
Evaluation of chemical immersion treatments to reduce microbial populations in fresh beef
}

\author{
Ahmed Kassem $^{\mathrm{a}, \mathrm{c}, \mathrm{e}, *}$, Joseph Meade ${ }^{\mathrm{a}}$, James Gibbons ${ }^{\mathrm{a}, \mathrm{c}}$, Kevina McGill ${ }^{\mathrm{a}}$, Ciara Walsh ${ }^{\mathrm{d}}$, \\ James Lyng ${ }^{\mathrm{b}, \mathrm{c}}$, Paul Whyte ${ }^{\mathrm{a}, \mathrm{c}}$ \\ ${ }^{a}$ School of Veterinary Medicine, University College Dublin, Belfield, Dublin 4, Ireland \\ b School of Agriculture and Food Science, University College Dublin, Belfield, Dublin 4, Ireland \\ ' UCD Centre for Food Safety, University College Dublin, Belfield, Dublin 4, Ireland \\ d School of Food Science \& Environmental Health, Dublin Institute of Technology, Cathal Brugha St., Dublin, Ireland

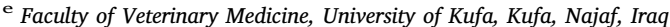

A R T I C L E I N F O

Chemical compounds studied in this article:

Acetic acid (PubChem CID:176)

Citric acid (PubChem CID:311)

lactic acid (PubChem CID:612)

sodium decanoate (PubChem CID:4457968)

trisodium phosphate (PubChem CID:24243)

Keywords:

Organic acids

Trisodium phosphate

Immersion

Meat color

Decontamination

Foodborne pathogens

\begin{abstract}
A B S T R A C T
The aim of the current study was to assess the ability of a number of chemicals (acetic Acid (AA), citric acid (CA) lactic acid (LA), sodium decanoate (SD) and trisodium phosphate (TSP)) to reduce microbial populations (total viable count, Campylobacter jejuni, Escherichia coli, Salmonella typhimurium and Listeria monocytogenes) on raw beef using an immersion system. The following concentrations of each chemical were used: $3 \& 5 \%$ for AA, CA, LA, SD and $10 \& 12 \%$ for TSP. Possible synergistic effects of using combinations of two chemicals sequentially (LA + CA and LA + AA) were also investigated. $\mathrm{L}^{*}, \mathrm{a}^{*}$ and $\mathrm{b}^{*}$ values were measured before and after treatments and $\Delta \mathrm{E}^{*}$ values were calculated in order to determine any changes in the color of meat due to the use of these chemicals. In general, all chemical treatments resulted in significantly $(p<0.05)$ reduced bacterial counts when compared to untreated controls. The greatest reductions were obtained by using LA3\%, SD5\%, AA5\%, LA5\% and SD3\% for TVC, C. jejuni, E. coli, S. typhimurium and L. monocytogenes, respectively. However, no significant difference in microbial load was observed between the different concentrations of each chemical used ( $p>0.05$ ). The application of combinations of chemical immersion treatments (LA3\% + AA3\% and LA3\% $+\mathrm{CA} 3 \%$ ) did not result in further significant reductions in microbial populations when compared to single chemical treatments $(P<0.05)$. Assessment of color changes in meat following the application of chemical immersion treatments indicated that using AA or CA at either concentration and LA at 5\% led to an increase in the $\Delta \mathrm{E}^{*}$ value of $>3$ immediately after treatment and after $24 \mathrm{~h}$ storage. The remaining treatments did not result in significant changes to the color of raw beef.
\end{abstract}

\section{Introduction}

Foodborne disease is a global health issue causing significant morbidity and mortality. It has been estimated that, globally, 1 in 10 people fall ill every year from eating contaminated food and 420,000 die as a result, with children comprising a substantial proportion of this estimate (WHO, 2015). The European Food Safety Authority (EFSA) reported campylobacteriosis, salmonellosis, listeriosis and E. coli (VTEC) infection as the main bacterial foodborne diseases for humans in 2015, with the number of cases at 229,213, 94,625, 2206 and 5901 respectively (EFSA, 2016). These pathogens (Campylobacter, Salmonella, E. coli and Listeria) are frequently associated from meat and meat products (Kramarenko et al., 2016; Tafida et al., 2013; Whyte et al., 2004; Yang et al., 2016). Due to potential food safety concerns associated with meat products, the food industry has continued to assess potential risk mitigation strategies to reduce pathogen populations on raw meat. The application of organic acids has been investigated as a possible technology to reduce bacterial levels in many foods especially meat and meat products (Lucera et al., 2012). EFSA has stated that lactic acid treatments can result in significant reductions in microbial counts when used to treat beef carcasses (EFSA, 2011). The mechanism of action of organic acids is dependent on the ability of undissociated acid to permeate through the cell membrane and dissociate inside the bacteria causing a decrease in internal $\mathrm{pH}$, which may interrupt ATP and RNA synthesis, DNA replication and cell growth (Rajkovic et al., 2010).

Organic acids have been approved for use in the area of meat decontamination in the United States (USDA-FSIS, 1996) and are now routinely used in many countries to reduce bacterial contamination

\footnotetext{
* Corresponding author at: School of Veterinary Medicine, University College, Dublin, Belfield, Dublin 4, Ireland.

E-mail address: ahmed.hushimat@ucdconnect.ie (A. Kassem).
} 
(Theron and Lues, 2010). However, to date, European authorities have preferred the application of strict hygiene measures during processing as the primary risk management approach. More recently the use of lactic acid for the decontamination of beef carcasses has been approved by the European Commission (2013). In addition to organic acids, many other chemicals have been assessed for meat decontamination such as trisodium phosphate (TSP) (Dickson et al., 1994). Trisodium phosphate has been used in the United States for decontamination of chicken carcasses using concentrations of $10-12 \%$; this chemical also has generally recognized as safe (GRAS) status and does not require labeling (Lianou and Koustsoumanis, 2012). Many studies have investigated the effect of organic acids at concentrations of between 1 and 5\% and TSP between 8 and $12 \%$ to decontaminate beef carcasses or beef cuts using spray methods (Barboza de Martinez et al., 2002; Cutter and Siragusa, 1994; Gill and Badoni, 2004; Gorman et al., 1995). However, few studies have investigated these chemicals on beef cuts using immersion treatments while also assessing their impact on organoleptic properties. These chemical treatments could be used to dip whole carcasses or, for example, on beef trimmings either before their use as a raw material for ground beef or prior to packing as cuts for direct consumption. Beef trimmings are frequently contaminated with pathogenic bacteria due to mixing of meat from different animals (Pohlman et al., 2002b). Furthermore, levels of contamination in beef trimmings can directly affect the bacterial quality of ground beef (Dorsa et al., 1998). Treatment with chemical or physical interventions may result in the survival of a population of bacteria some of which may be sub-lethally injured (Wesceie et al., 2009). However, injured cells may repair and remain viable if allowed maintained in non-stressful conditions (Jasson et al., 2007). Therefore, it is important to consider the presence of sub-lethally injured cells when estimating the effectiveness of bacterial deactivation methods in order to prevent the generation of inaccurate results (Wu, 2008).

Avoiding substantive changes in the color of raw beef is also an important consideration when assessing the suitability of individual chemical compounds as potential microbial decontaminants (Hunt et al., 2012). This is a key sensory property used by consumers to decide whether they should accept or reject meat products (Mancini and Hunt, 2005). Certain organic acids may cause a permanent discoloration (dull gray color) when applied to raw meat (Wenham and Locker, 1976).

A review by EFSA of a number of studies on the use of organic acids for the decontamination of beef concluded that concentration may influence the efficacy of bacterial reduction (EFSA, 2011). Furthermore, to the author's knowledge few studies have determined the effect of a water rinsing step treatment following treatment of beef (EFSA, 2011).

This study was carried out to:

(i) compare the effect of different concentrations of various chemical immersion treatments and water immersion on microbial populations in fresh beef (ii) assess the efficacy of using combinations of two of these chemicals on microbial reductions

(ii) investigate any potential undesirable color changes in meat due to these chemical treatments

(iii) estimate the level of sub-lethally injured cells following treatments.

\section{Materials and methods}

\subsection{Preparation of bacterial suspensions and inoculation of samples}

Salmonella typhimurium (DT104), Campylobacter jejuni (1146 chicken isolate), Listeria monocytogenes (NCTC11994) and Escherichia coli (ATCC25922) were used in the study. Suspensions of $C$. jejuni were prepared by inoculating $20 \mathrm{ml}$ aliquots of Mueller-Hinton Broth (MHB) (Oxoid, UK, CM0405) containing Campylobacter growth supplement with a single colony of the isolate and incubated for $24 \mathrm{~h}$ at $42^{\circ} \mathrm{C}$ under microaerobic conditions. A total of ten of the $20 \mathrm{ml}$ aliquots were then combined to make up $200 \mathrm{ml}$ volumes, and diluted with $300 \mathrm{ml}$ of maximum recovery diluent MRD, (OxoidCM0733) to give a $500 \mathrm{ml}$ volume containing a cell concentration of approximately $7 \log _{10} \mathrm{cfu} /$ $\mathrm{ml}$. Individual colonies of $S$. Typhimurium, E. coli and L. monocytogenes were inoculated in 10 tubes each containing $20 \mathrm{ml}$ of MHB and were then incubated for $24 \mathrm{~h}$ at $37^{\circ} \mathrm{C}$. Liquid from the 10 tubes were then pooled to give a $200 \mathrm{ml}$ volume and made up to a final volume of $500 \mathrm{ml}$ by adding $300 \mathrm{ml}$ of sterile MRD. This corresponded to final cell concentrations of 8-9 $\log _{10} \mathrm{cfu} / \mathrm{ml}$. Fresh beef was purchased from retail outlets and cut into $10 \mathrm{~g}$ pieces. Three samples were used for each treatment and dipped for $60 \mathrm{~s}$ in the $500 \mathrm{ml}$ volumes of each bacterial suspension and left for $30 \mathrm{~min}$ prior to applying the various treatments to allow for attachment.

\subsection{Chemical treatments}

Each experiment was repeated in triplicate on three separate occasions. All samples $(n=3)$ were dipped in appropriate $500 \mathrm{ml}$ chemical solutions for $60 \mathrm{~s}$ (stirring for $10 \mathrm{~s}$ ) at room temperature. Samples were treated with either $3 \%$ or $5 \%$ of acetic acid (AA) (Sigma-Aldrich, USA, 320099), citric acid (CA) (Sigma-Aldrich, USA, C0759), lactic acid (LA) (Sigma-Aldrich, USA, W261114), sodium decanoate (SD) (SigmaAldrich, USA, C4151) and $10 \%$ or $12 \%$ of trisodium phosphate (TSP) (Sigma-Aldrich, USA, 222003) respectively. Following treatment, samples were immersed in $500 \mathrm{ml}$ distilled water for $15 \mathrm{~s}$ to rinse off any residual chemical. Washed control (WC) samples were treated similarly, but in distilled water only prior to microbiological analysis. Untreated control samples (UC) were microbiologically analyzed directly without any treatment to determine the background microflora. For combined chemical treatments (LA + CA and LA + AA), samples were immersed sequentially in the first chemical solution and rinsed in water before immersion in the second solution to limit any potential chemical interaction. Samples were immersed for $60 \mathrm{~s}$ in each of the chemical solutions.

\subsection{Microbiological analysis}

Samples were stomached (Colworth Stomacher 400 series, UK) for $30 \mathrm{~s}$ in $90 \mathrm{ml} \mathrm{MRD}$, and serially diluted (1:9) in MRD before being plated in duplicate onto modified Charcoal Cefoperazone Deoxycholate (mCCDA) (Oxoid, UK, CM0739) containing a selective supplement (Oxoid, UK, SR0155E) and incubated microaerobically at $42{ }^{\circ} \mathrm{C}$ for $48 \mathrm{~h}$ for Campylobacter enumeration. Samples were also plated in duplicate for total viable counts on plate count agar (PCA) (Oxoid, UK, CM0325) and incubated at $30{ }^{\circ} \mathrm{C}$ for $48 \mathrm{~h}$ ), Violet Red Bile Agar (VRBA) + MUG (Oxoid, UK, CM0978) for E. coli, Xylose Lysine Desoxycholate Agar (X.L.D.) (Oxoid, UK, CM0469) for S. typhimurium and Listeria selective agar base (Oxford formulation), (Oxoid, UK, CM0856) with Listeria selective supplement (Oxford formulation) (Oxoid, UK, SR0140E) for $L$. monocytogenes. E. coli, Salmonella and Listeria plates were incubated at $37^{\circ} \mathrm{C}$ for $24 \mathrm{~h}$.

\subsection{Meat color analysis}

Three fresh meat samples were dipped in each chemical as previously described. Color measurements were then taken for each sample from three different locations directly before and after chemical treatment as well as following storage for $24 \mathrm{~h}$ at $4{ }^{\circ} \mathrm{C}$. Color measurement was carried out using a Konica Minolta device (model CR-400) according to the CIELAB international system of color measurement. The device was calibrated with a white ceramic tile, in accordance with the manufacturer's instructions. The device reads three color parameters $\left(\mathrm{L}^{*}(+=\right.$ lighter, $-=$ darker $), \mathrm{a}^{*}(+=$ redder, $-=$ greener $)$ and $\mathrm{b}^{*}$ $(+=$ yellower, $-=$ bluer $)$ ). Overall differences in color $\left(\Delta \mathrm{E}^{*}\right)$ were calculated using these three parameters in the following formula: $\Delta \mathrm{E}^{*}=\left[\left(\Delta \mathrm{L}^{*}\right)^{2}+\left(\Delta \mathrm{a}^{*}\right)^{2}+\left(\Delta \mathrm{b}^{*}\right)^{2}\right] 1 / 2$ (Tobergte and Curtis, 2013). 
Values of $\Delta \mathrm{E}^{*}>3$ were considered unacceptable for consumers (Francis and Clydesdale, 1975). All experiments were carried out in triplicate.

\subsection{Estimation of the percentage of sub-lethally injured cells}

A $10 \mathrm{ml}$ volume of overnight bacterial cultures (Tryptone Soya Broth (TSB) (Oxoid, UK, CM0129) for E coli, S. typhimurium and $L$. monocytogenes and MHB for $C$. jejuni) of each microorganism was prepared by centrifugation and removal of the supernatants. Five milliliters volumes of each treatment solution was prepared (3\% AA, CA, LA and SD and 10\% TSP) and transferred to the bacterial pellets and vortexed for about $10 \mathrm{~s}$. After $60 \mathrm{~s}$ exposure, each $5 \mathrm{ml}$ bacterial suspension was then transferred to $45 \mathrm{ml}$ of MRD to dilute the chemical concentration and prevent further exposure to the chemicals. Each $50 \mathrm{ml}$ bacterial solution was centrifuged and $35 \mathrm{ml}$ of the supernatant was removed. The remaining $15 \mathrm{ml}$ was then transferred into $20 \mathrm{ml}$ tubes and centrifuged. Following centrifugation, the remaining supernatant was removed and the pellets were resuspended in $5 \mathrm{ml}$ and vortexed. The bacterial solutions were then serially diluted and cultured on selective media (VRBA + MUG for E. coli, X.L.D. for Salmonella, Listeria selective agar base with Listeria selective supplement for Listeria and CCDA for Campylobacter) and on non-selective media (Tryptone Soya Agar (TSA) (Oxoid, UK, CM0131) for E. coli, Salmonella and Listeria) and (Mueller Hinton agar (MHA) for Campylobacter). The plates were incubated for extended period to ensure that any injured cells were given additional time to repair and grow $\left(37^{\circ} \mathrm{C}\right.$ for $48 \mathrm{~h}$ for $E$. coli and Salmonella and $72 \mathrm{~h}$ for Listeria and Campylobacter. Counts were carried out to compare the difference between in numbers of colonies on selective and non-selective media. Each experiment was carried out in triplicate.

\subsection{Statistical analysis}

Microbial counts were converted to $\log _{10} \mathrm{cfu} / \mathrm{g}$. Mean bacterial counts between various treatment groups and controls were compared using a 1-way ANOVA followed by Tukey's Multiple Comparison test. Similarly, individual color component measurements were compared immediately after treatment and following $24 \mathrm{~h}$ ' storage using a 1-way ANOVA followed by Tukey's Multiple Comparison test. Significance was determined at the $p<0.05$ level. Data was analyzed using IBM SPSS software (IBM SPSS statistics 20 Software, Armonk, New York, United States, www.IBM.com).

\section{Results}

\subsection{Single chemical treatments}

In general, all chemical treatments resulted in significant reductions in bacterial counts (TVC, C. jejuni, E. coli, S. typhimurium and L. monocytogenes) when compared to corresponding controls (Table 1). Chemical treatments at the higher concentrations did not result in significantly greater reductions in microbial populations when compared to the lower concentrations used $(p>0.05)$. When untreated controls and wash control (WC) samples were compared, only Campylobacter levels were found to be significantly reduced by washing $(p<0.05)$. For total viable counts, all the chemical treatments applied resulted in significant reductions $(p<0.05)$ when compared to untreated controls. Only treatment with LA 3\% and LA 5\% resulted in significantly $(p<0.05)$ lower TVC counts compared with WC (Table 1). For C. jejuni, significant reductions $(p<0.05)$ for all treatments were observed when compared to washed controls. SD 5\% was significantly $(p<0.05)$ better than all of the other chemicals tested and reduced Campylobacter levels by $2.9 \log \mathrm{cfu} / \mathrm{g}$. For E. coli and S. typhimurium, all chemical treatments significantly reduced bacterial counts when compared to untreated and washed controls $(p<0.05)$ (Table 1). The

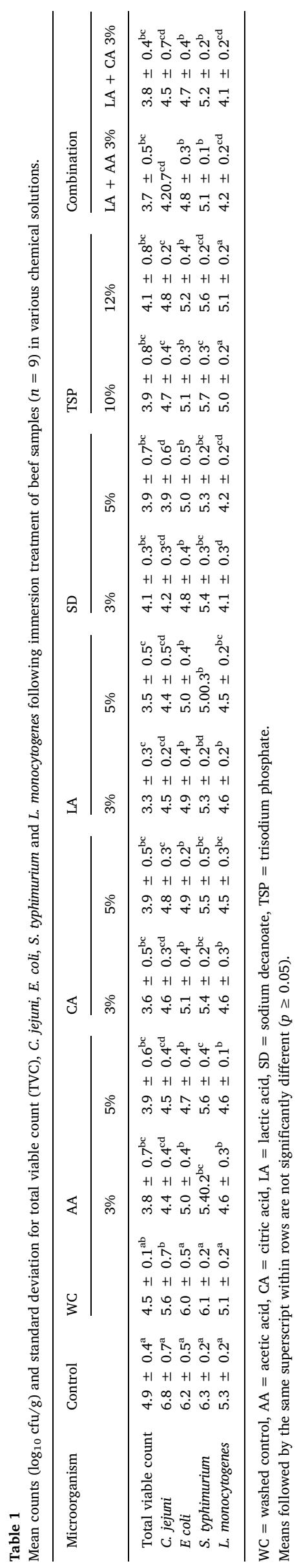


greatest reduction in $E$. coli numbers was observed after treatment with AA 5\%. Treatment with LA 5\% showed the greatest reduction (1.3 $\log \mathrm{cfu} / \mathrm{g})$ in Salmonella when compared to the other chemicals examined in the current study. For L. monocytogenes, washed control samples, and those treated with TSP (10\& $12 \%)$ showed no significant reductions when compared to samples in the untreated control group $(p>0.05)$. The other chemical treatments significantly reduced $(p<0.05)$ Listeria counts when compared to untreated and washed controls. Sodium decanoate at either concentration (3 or 5\%) gave the greatest reductions in Listeria levels compared to untreated control samples $(p<0.05)$.

\subsection{Chemicals combinations}

The effect of applying sequential combinations of two chemical immersion treatments was also investigated (LA + AA, LA + CA) to assess whether multiple treatments would result in a synergistic or enhanced level of microbial reduction (Table 1). Results showed a significant reduction $(p<0.05)$ in bacterial counts between combination treatments and both water immersion and untreated control groups. However, for TVC, C. jejuni, E. coli and Salmonella, there was no significant $(p>0.05)$ additional reductions achieved in bacterial counts when combination treatments were compared with their single chemical treatments. In the case of L. monocytogenes, both combination treatments showed a significant bacterial reduction when compared to each individual treatment.

\subsection{Color analysis}

When samples were analyzed (Table 2), it was found that the $\mathrm{L}^{*}$ value increased significantly for WC, AA3 $\%$, AA $5 \%$, CA3 $\%$, CA $5 \%$ treatments when compared to untreated controls at both time points $(p<0.05)$. The $L^{*}$ value for AA5\% was highest compared to untreated controls ( 45.62 at time 0 and 44.69 at $24 \mathrm{~h}$ after treatment). In contrast, the $\mathrm{L}^{*}$ values for TSP $10 \%$ were significantly lower compared to controls suggesting a darkening of the meat due to the chemical treatment $(p<0.05)$. Results for a* values (redness) showed a significant decrease $(p<0.05)$ for WC, AA3\%, AA5\%, CA3\%, CA5\%, LA3\%, LA5\% and TSP $12 \%$ immediately following treatment and $24 \mathrm{~h}$ after storage at $4{ }^{\circ} \mathrm{C}$ compared with untreated controls. With the exception of CA5\% and LA5\%, there was no significant difference between wash control and treated samples when a* values were compared.

Results also showed a significant increase $(p<0.05)$ in $\mathrm{b}^{*}$ values (yellowness) for WC, AA3\% and AA5\%, while a significant $(p<0.05)$ decrease was observed for CA5\% immediately after treatment.

Table 2

Changes in mean lightness $\left(\mathrm{L}^{*}\right)$, redness $\left(\mathrm{a}^{*}\right)$ and yellowness $\left(\mathrm{b}^{*}\right)$ values of beef at time 0 and $24 \mathrm{~h}$ following chemical treatments.

\begin{tabular}{|c|c|c|c|c|c|c|}
\hline \multirow[t]{2}{*}{ Treatments $^{1}$} & \multicolumn{2}{|l|}{$L^{*}$} & \multicolumn{2}{|l|}{$a^{*}$} & \multicolumn{2}{|l|}{$b^{*}$} \\
\hline & Time 0 & After $24 \mathrm{~h}$ & Time 0 & After $24 \mathrm{~h}$ & Time 0 & After $24 \mathrm{~h}$ \\
\hline Control & $39.45^{\mathrm{a}}$ & $39.21^{\mathrm{a}}$ & $23.72^{\mathrm{a}}$ & $24.19^{\mathrm{a}}$ & $6.61^{\mathrm{a}}$ & $6.72^{\mathrm{a}}$ \\
\hline WC & $41.44^{\mathrm{b}}$ & $40.42^{\mathrm{a}}$ & $22.25^{\mathrm{b}}$ & $22.22^{\mathrm{b}}$ & $7.78^{\mathrm{b}}$ & $7.65^{\mathrm{b}}$ \\
\hline AA3 & $42.06^{\mathrm{b}}$ & $41.60^{\mathrm{b}}$ & $21.18^{\mathrm{b}}$ & $21.15^{\mathrm{b}}$ & $7.54^{\mathrm{b}}$ & $7.47^{\mathrm{b}}$ \\
\hline AA5 & $45.62^{\mathrm{b}}$ & $44.69^{b}$ & $21.85^{\mathrm{b}}$ & $21.12^{\mathrm{b}}$ & $9.79^{\mathrm{b}}$ & $10.26^{\mathrm{c}}$ \\
\hline CA3 & $41.98^{\mathrm{b}}$ & $41.69^{b}$ & $21.01^{\mathrm{b}}$ & $20.48^{\mathrm{b}}$ & $6.82^{a}$ & $7.12^{\mathrm{a}}$ \\
\hline CA5 & $41.76^{\mathrm{b}}$ & $41.68^{\mathrm{b}}$ & $18.59^{b}$ & $18.61^{\mathrm{b}}$ & $5.79^{c}$ & $6.22^{\mathrm{a}}$ \\
\hline LA3 & $40.41^{\mathrm{a}}$ & $40.26^{\mathrm{a}}$ & $21.36^{\mathrm{b}}$ & $21.33^{\mathrm{b}}$ & $6.39^{\mathrm{a}}$ & $6.41^{\mathrm{a}}$ \\
\hline LA5 & $40.73^{\mathrm{a}}$ & $40.67^{\mathrm{b}}$ & $20.17^{\mathrm{b}}$ & $18.47^{\mathrm{b}}$ & $6.10^{\mathrm{a}}$ & $6.75^{\mathrm{a}}$ \\
\hline SD3 & $38.79^{\mathrm{a}}$ & $39.10^{\mathrm{a}}$ & $21.28^{\mathrm{b}}$ & $20.96^{\mathrm{b}}$ & $6.50^{\mathrm{a}}$ & $6.45^{\mathrm{a}}$ \\
\hline SD5 & $40.33^{\mathrm{a}}$ & $40.24^{\mathrm{a}}$ & $22.32^{\mathrm{b}}$ & $21.29^{\mathrm{b}}$ & $6.50^{\mathrm{a}}$ & $6.51^{\mathrm{a}}$ \\
\hline TSP10 & $37.28^{\mathrm{c}}$ & $37.29^{c}$ & $23.99^{\mathrm{a}}$ & $23.88^{\mathrm{a}}$ & $5.93^{\mathrm{a}}$ & $6.21^{\mathrm{a}}$ \\
\hline TSP12 & $38.96^{\mathrm{a}}$ & $38.97^{\mathrm{a}}$ & $21.83^{\mathrm{b}}$ & $21.72^{\mathrm{b}}$ & $6.02^{\mathrm{a}}$ & $6.03^{\mathrm{a}}$ \\
\hline
\end{tabular}

${ }^{1} \mathrm{WC}=$ washed control, $\mathrm{AA}=$ acetic acid, $\mathrm{CA}=$ citric acid, LA = lactic acid, $\mathrm{SD}=$ sodium decanoate, $\mathrm{TSP}=$ trisodium phosphate.
Table 3

Total color difference $\left(\Delta \mathrm{E}^{*}\right)$ values of meat color calculated at 0 and $24 \mathrm{~h}$ following chemical treatments.

\begin{tabular}{lll}
\hline Treatments $^{\mathrm{a}}$ & $\Delta \mathrm{E}^{*}$ time $0^{\mathrm{b}}$ & $\Delta \mathrm{E}^{*}$ after $24 \mathrm{~h}^{\mathrm{b}}$ \\
\hline Control & 0 & 0.87 \\
WC & 2.76 & 2.64 \\
AA3 & 3.86 & 4.03 \\
AA5 & 7.31 & 7.31 \\
CA3 & 3.79 & 4.61 \\
CA5 & 5.77 & 6.21 \\
LA3 & 2.73 & 2.88 \\
LA5 & 3.86 & 5.95 \\
SD3 & 2.80 & 2.83 \\
SD5 & 1.78 & 2.82 \\
TSP10 & 2.42 & 2.17 \\
TSP12 & 2.18 & 2.71
\end{tabular}

a $\mathrm{WC}=$ washed control, $\mathrm{AA}=$ acetic acid, $\mathrm{CA}=$ citric acid, $\mathrm{LA}=$ lactic acid, $\mathrm{SD}=$ sodium decanoate, $\mathrm{TSP}=$ trisodium phosphate

${ }^{\mathrm{b}} \Delta \mathrm{E}^{*}>3$ indicated color changes detectable to the human eye.

The study showed that the type of chemical and concentration could affect the $\Delta \mathrm{E}$ values (Table 3 ). According to Francis and Clydesdale (1975) when color differences $\left(\Delta \mathrm{E}^{*}\right)$ exceed a value of 3 , they are detectable to the human eye. The $\Delta \mathrm{E}^{*}$ values for WC, LA3\%, SD3\%, SD5\%, TSP $10 \%$ and TSP $12 \%$ were $<3$ both at time 0 and $24 \mathrm{~h}$ after treatment when stored at $4{ }^{\circ} \mathrm{C}$. In contrast, treatments with AA3\%, AA5\%, CA3\%, CA5\% and LA5\% resulted in $\Delta \mathrm{E}^{*}$ values $>3$ at both time points which are more likely to be detected by consumers.

\subsection{Estimating percentage of sub-lethally injured cells in selective media}

Results of this experiment showed no significant difference $(p<0.05)$ between the selective and non-selective media to recover the microorganisms used in this study (data not shown). From this we can conclude that sub-lethal injury was not significant and that the results of our study accurately reflect the levels of microbial reduction achieved for each of the chemical treatments and each group of organisms studied.

\section{Discussion}

Our study investigated the effect of applying five chemicals at two different concentrations on microbial populations in raw beef. In addition, we assessed the potential of using combinations of these compounds sequentially to enhance the decontamination effect as few studies have investigated possible synergistic effects when applying more than one chemical. The impact of these treatments on color was also established as such changes in sensory properties need to be evaluated when considering the suitability of chemical decontaminant treatments for fresh meat (EFSA, 2011).

Many studies have investigated the effect of organic acids and other chemicals as treatments to reduce bacterial levels in raw beef. However, to the authors' knowledge, few studies have examined the effect of a washing step immediately following chemical treatment. Incorporation of such a washing step has two potential effects; it limits the exposure time of microorganisms to the chemical and may act to physically remove microorganisms from the surface of the meat (EFSA, 2011; Koolman et al., 2014). Results of the current study showed that all chemical treatments resulted in significant reductions in microbial populations when compared to untreated controls; however, in general, no additional benefit was observed when treatments were carried out using chemicals at the higher concentrations. When samples were immersed in sterile water only, it was found that significant reductions in Campylobacter counts were observed when compared to untreated controls, with no corresponding reductions in levels of TVC, E. coli, Salmonella and Listeria. This observation could be due to the 
morphological characteristics of Campylobacter and its adherence capability. Campylobacter generally exhibit a slim spiral or curved form in their preferred environment, but under aerobic conditions and at room temperature, as used in this study, Campylobacter cells can convert to their coccoid form which has less attachment ability (Jang et al., 2007).

Trisodium phosphate (TSP) has been reported to cause damage to lipid components within the bacterial cell membrane (Oyarzabal, 2005). Gram negative bacteria have been shown to be more susceptible to TSP than Gram positive bacteria due to differences in cell wall structure (Capita et al., 2002; Su and D'Souza, 2012). This agrees with our study where all Gram negative organisms (Campylobacter, E. coli and Salmonella) decreased significantly in number after exposure to TSP, while Gram-positive Listeria did not. These results also agree with the findings of other studies where TSP was less effective to reduce $L$. monocytogenes than $S$. typhimurium and E. coli in beef (Dickson et al., 1994; Pohlman et al., 2002a, 2002b). The greatest reduction in bacterial numbers following TSP treatment was observed for $C$. jejuni $(\sim$ $2 \log _{10} \mathrm{cfu} / \mathrm{g}$ ). As well as causing bacterial cell death by destruction of the cell membrane, TSP is also believed to have a detergent effect resulting in detachment of cells from meat surfaces (Cabedo et al., 1996; Chen et al., 2012; Dinçer and Baysal, 2004; Gorman et al., 1995).

Sodium decanoate is a sodium salt of capric acid which is a medium chain fatty acid. Results of our study showed that $C$. jejuni was more susceptible to sodium decanoate than the other microorganisms, and $S$. typhimurium was the most resistant. Medium chain fatty acids have been shown to cause damage to the cell membrane (Thormar et al., 2006); however, the cell wall of Gram-positive bacteria and the outer membrane of Gram-negative bacteria may act as protection against fatty acids (Desbois and Smith, 2010). Differences in the outer lipopolysaccharide layer may account for the difference in results observed between Gram-negative bacterial species in this study (Hinton, 2011).

With the exception of $L$. monocytogenes neither of the two combination treatments used in this study (LA3\% + AA and LA3\% + CA3\%) demonstrated a synergistic effect compared to their individual treatments. Previous studies on chemical combinations are few and have found conflicting results depending on experimental conditions and the chemicals selected (Loretz et al., 2011). It is possible that further reductions in bacterial numbers were not observed when combination treatments were applied as the chemicals used were from the same class and likely have the same mode of action.

One of the principal determinants of meat color is the oxidative state of the myoglobin molecule in muscle fibers which is dependent on changes within the metmyoglobin reducing activity cycle. The molecule may either be oxidized to the metmyoglobin state (brown color) or the meat may have enough reducing equivalents to allow it to be converted to one of two reduced states, myoglobin or oxymyoglobin (Hunt et al., 2012). Changes in $\mathrm{pH}$ can also influence the color of meat after treatment with chemicals (Enokimoto et al., 2007; Olivera et al., 2013). It has been reported that organic acids may reduce the lightness and redness of meat because they cause myoglobin oxidation by decreasing muscle $\mathrm{pH}$. For instance, acetic acid was associated with lighter colored beef due to less oxymyoglobin and, consequently, less redness of the meat surface (Stivarius et al., 2002). Types and concentration of acid treatment can influence the degree of meat discoloration due to differences in $\mathrm{pH}$. For example, lactic acid has been shown to have little or no effect on meat color which is in agreement with the findings of the current study (Jimenez-Villarreal et al., 2003a). In contrast, treatment with alkaline chemicals, such as TSP, results in increased $\mathrm{pH}$ which, in turn, leads to increased oxymyoglobin, redness and darkness of meat (Jimenez-Villarreal et al., 2003b; Mancini and Hunt, 2005). The finding of the current study that TSP treatment resulted in increased redness and darkness of meat is also in agreement with previous research (Pohlman et al., 2002a, 2002b). It has been suggested that the use of $\Delta \mathrm{E}^{*}$ values may be a more effective approach to determine whether color changes are detectable by the human eye (Tobergte and Curtis, 2013). According to Francis and Clydesdale (1975), when $\Delta E^{*}$ exceeds three, changes in meat color are visually detectable. In the current study treatments with AA and CA at either concentration resulted in $\Delta \mathrm{E}^{*}$ values greater than three and so are unlikely to meet with consumer acceptance.

\section{Conclusion}

This study demonstrates that treatment of beef in an immersion system with AA, CA, LA, SD and TSP was effective at reducing populations of pathogenic and spoilage bacteria. In general, the treatment of meat samples sequentially with 2 chemicals did not result in enhanced levels of microbial inactivation when compared to single chemical treatments. Treatment of raw beef with either AA or CA under the conditions described in this study resulted in changes to sample color which may affect consumer acceptance. Our study demonstrated that LA3\%, SD $3 \%$ and TSP $10 \%$ could be practical immersion treatments to reduce pathogenic bacteria without affecting beef color.

\section{Acknowledgement}

The authors wish to acknowledge the financial support of the Iraqi Ministry of Higher Education and the University of Kufa.

Means followed by the same superscript within columns are not significantly different $(p \geq 0.05)$.

There was no significant difference in any color parameters within treatments when compared at time 0 and $24 \mathrm{~h}(p \geq 0.05)$.

\section{References}

Barboza de Martinez, Yasmina, Ferrer, Kenna, Salas, Enrique Marquez, 2002. Combined effects of lactic acid and nisin solution in reducing levels of microbiological contamination in red meat carcasses. J. Food Prot. 65 (11), 1780-1783. Retrieved May 19, 2017. http://www.ncbi.nlm.nih.gov/pubmed/12430703.

Cabedo, L., Sofos, J.N., Smith, G.C., 1996. Removal of bacteria from beef tissue by spray washing after different times of exposure to fecal material. J. Food Prot. 59 (12), 1284-1287.

Capita, R., Alonso-Calleja, C., Garcia-Fernandez, M.C., Moreno, B., 2002. Review: trisodium phosphate (TSP) treatment for decontamination of poultry. Food Sci. Technol. Int. 8 (1), 11-24. Available at: http://dx.doi.org/10.1106/108201302023118.

Chen, J.H., Ren, Y., Seow, J., Liu, T., Bang, W.S., Yuk, H.G., 2012. Intervention technologies for ensuring microbiological safety of meat: current and future trends. Compr. Rev. Food Sci. Food Saf. 11 (2), 119-132.

Cutter, C.N., Siragusa, G.R., 1994. Decontamination of beef carcass tissue with nisin using a pilot scale model carcass washer. Food Microbiol. 11, 481-489.

Desbois, A.P., Smith, V.J., 2010. Antibacterial free fatty acids: activities, mechanisms of action and biotechnological potential. Appl. Microbiol. Biotechnol. 85 (6), 1629-1642.

Dickson, J.S., Cutter, C.G.N., Siragusa, G.R., 1994. Antimicrobial effects of trisodium phosphate against bacteria attached to beef tissue. J. Food Prot. 57 (11), 952-955.

Dinçer, a H., Baysal, T., 2004. Decontamination techniques of pathogen bacteria in meat and poultry. Crit. Rev. Microbiol. 30 (3), 197-204.

Dorsa, W.J., Cutter, C.N., Siragusa, G.R., 1998. Long-term bacterial profile of refrigerated ground beef made from carcass tissue, experimentally contaminated with pathogens and spoilage bacteria after hot water, alkaline, or organic acid washes. J. Food Prot. 61 (12), 1615-1622.

Enokimoto, M., Kubo, M., Bozono, Y., Mieno, Y., Misawa, N., 2007. Enumeration and identification of campylobacter species in the liver and bile of slaughtered cattle. Int. J. Food Microbiol. 118, 259-263.

European Commission, 2013. Regulation (EC) N_101/2013 of the European Parliament and of the Council of 4 February 2013 Concerning the use of lactic acid to reduce microbiological surface contamination on bovine carcasses. Off. J. Eur. Union 9 (7), 2011-2013.

European Food Safety Authority (EFSA), 2011. Scientific Opinion on the evaluation of the safety and efficacy of lactic acid for the removal of microbial surface contamination of beef carcasses, cuts and trimmings. EFSA J. 9 (7), 2317. 35 pp. Available at: http://scholar.google.com/scholar?hl= en\&btnG = Search\&q = intitle:Scientific + Opinion + on + the + evaluation + of + the + safety + and + efficacy + of + lactic + acid + for + the + removal + of + microbial + surface + contamination + of + beef + carcasses,++ cuts $\# 8$.

European Food Safety Authority (EFSA), 2016. The European Union summary report on trends and sources of zoonsoes, zoonotic agents and food-borne outbreaks in 2015. EFSA J. 14 (12) Available at: https://www.efsa.europa.eu/sites/default/files/ scientific_output/files/main_documents/4329.pdfhttps://www.efsa.europa.eu/sites/ default/files/scientific_output/files/main_documents/4329.pdf (November).

Francis, F.J., Clydesdale, F.M., 1975. Food colorimetry: Theory and Applications. AVI, Westport, Conn.

Gill, C., Badoni, M., 2004. Effects of peroxyacetic acid, acidified sodium chlorite or lactic 
acid solutions on the microflora of chilled beef carcasses. Int. J. Food Microbiol. 91 (1), 43-50.

Gorman, B.M., Sofos, J.N., Morgan, J.B., Schmidt, G.R., Smith, G.C., 1995. Evaluation of hand-trimming, various sanitizing agents, and hot water spray-washing as decontamination interventions for beef brisket adipose tissue. J. Food Prot. 58 (8), 899-907.

Hinton Jr., A., 2011. Bactericidal activity of alkaline salts of fatty acids towards bacteria associated with poultry processing - Engormix. In XXII Latin American Poultry Congress 2011. Buenos Aires, Argentina: Meeting Proceedings, pp. 156. Available at: http://en.engormix.com/MA-poultry-industry/health/articles/bactericidal-activityalkaline-salts-t1747/165-p0.htm, Accessed date: 8 February 2017.

Hunt, M.C., King, A., Barbut, S., Clause, J., Cornforth, D., Hanson, D., Lindahl, G., Mancini, R., Milkowski, A., Mohan, A., 2012. AMSA Meat Color Measurement Guidelines, Champaign, Illinois.

Jang, K.-I., Kim, M.-G., Ha, S.-D., Kim, K.-S, LEE, K.-H., Duck-Hwa Chung, C.-H.K., Kim, K.-Y., 2007. Morphology and adhesion of Campylobacter jejuni to chicken skin under varying conditions. J. Microbiol. Biotechnol. 17 (2), 202-206.

Jasson, V., Mieke, U., Andreja, R., Johan, D., 2007. Establishment of procedures provoking sub-lethal injury of Listeria monocytogenes, Campylobacter jejuni and Escherichia coli $\mathrm{O} 157$ to serve method performance testing. Int. J. Food Microbiol. 118 (3), 241-249.

Jimenez-Villarreal, J.R., Pohlman, F.W., Johnson, Z.B., Brown, A.H., 2003a. Lipid, instrumental color and sensory characteristics of ground beef produced using trisodium phosphate, cetylpypiridinium chloride, chlorine dioxide or lactic acid as multiple antimicrobial interventions. Meat Sci. 65 (2), 885-891.

Jimenez-Villarreal, J.R., Pohlman, F.W., Johnson, Z.B., Brown, A.H., Baublits, R.T. 2003b. The impact of single antimicrobial intervention treatment with cetylpyridinium chloride, trisodium phosphate, chlorine dioxide or lactic acid on ground beef lipid, instrumental color and sensory characteristics. Meat Sci. 65 (3), 977-984.

Koolman, L., Whyte, P., Meade, J., Lyng, J., Bolton, D., 2014. Use of chemical treatments applied alone and in combination to reduce Campylobacter on raw poultry. Food Control 46, 299-303. Available at: http://dx.doi.org/10.1016/j.foodcont.2014.05. 041.

Kramarenko, T., Roasto, M., Keto-Timonen, R., Mäesaar, M., Meremäe, K., Kuningas, M., Hörman, A., Korkeala, H., 2016. Listeria monocytogenes in ready-to-eat vacuum and modified atmosphere packaged meat and fish products of Estonian origin at retail level. Food Control 67, 48-52.

Lianou, A., Koustsoumanis, K.P., 2012. Organic acids and other chemical treatments for microbial decontamination of food. In: Demirci, A., Ngadi, M.O. (Eds.), Microbial Decontamination in the Food Industry: Novel Methods and Applications. Elsevier Ltd Available at: http://www.scopus.com/inward/record.url?eid = 2-s2.084902947236\&partnerID = tZOtx3y1.

Loretz, M., Stephan, R., Zweifel, C., 2011. Antibacterial activity of decontamination treatments for cattle hides and beef carcasses. Food Control 22 (3-4), 347-359. Available at: http://dx.doi.org/10.1016/j.foodcont.2010.09.004.

Lucera, A., Costa, C., Conte, A., Del Nobile, M.A., 2012. Food applications of natural antimicrobial compounds. Front. Microbiol. 3 (AUG), 1-13.

Mancini, R.A., Hunt, M.C., 2005. Current research in meat color. Meat Sci. 71 (1), 100-121.

Olivera, D.F., Bambicha, R., Laporte, G., Cárdenas, F.C., Mestorino, N., 2013. Kinetics of colour and texture changes of beef during storage. J. Food Sci. Technol. 50 (4), 821-825.

Oyarzabal, O.A., 2005. Reduction of Campylobacter spp. by commercial antimicrobials applied during the processing of broiler chickens: a review from the United States perspective. J. Food Prot. 68 (8), 1752-1760.

Pohlman, F.W., Stivarius, M.R., McElyea, K.S., Johnson, Z.B., Johnson, M.G., 2002a. Reduction of microorganisms in ground beef using multiple intervention technology. Meat Sci. 61 (3), 315-322.

Pohlman, F.W., Stivarius, M.R., McElyea, K.S., Waldroup, A.L., 2002b. Reduction of E. coli, Salmonella typhimurium, coliforms, aerobic bacteria, and improvement of ground beef color using trisodium phosphate or cetylpyridinium chloride before grinding. Meat Sci. 60 (4), 349-356.

Rajkovic, A., Smigic, N., Devlieghere, F., 2010. Contemporary strategies in combating microbial contamination in food chain. Int. J. Food Microbiol. 141, S29-S42. Available at: http://dx.doi.org/10.1016/j.ijfoodmicro.2009.12.019.

Stivarius, M.R., Pohlman, F.W., McElyea, K.S., Apple, J.K., 2002. The effects of acetic acid, gluconic acid and trisodium citrate treatment of beef trimmings on microbial, color and odor characteristics of ground beef through simulated retail display. Meat Sci. 60 (3), 245-252.

Su, X., D'Souza, D.H., 2012. Reduction of Salmonella typhimurium and Listeria monocytogenes on produce by trisodium phosphate. LWT Food Sci. Technol. 45 (2), 221-225. Available at: http://dx.doi.org/10.1016/j.lwt.2011.08.010.

Tafida, S.Y., Kabir, J., Kwaga, J.K., Bello, M., Umoh, V.J., Yakubu, S.E., Nok, A.J., Hendriksen, R., 2013. Occurrence of Salmonella in retail beef and related meat products in Zaria, Nigeria. Food Control 32 (1), 119-124.

Theron, M.M., Lues, J.F.R., 2010. Organic acids and food preservation, CRC Press. Available at: https://books.google.com/books?id=7IrGwQTt1aMC\&pgis =1, Accessed date: 21 May 2015.

Thormar, H., Hilmarsson, H., Bergsson, G., 2006. Stable concentrated emulsions of the 1 monoglyceride of capric acid (monocaprin) with microbicidal activities against the food-borne bacteria Campylobacter jejuni, Salmonella spp., and Escherichia coli. Appl. Environ. Microbiol. 72 (1), 522-526.

Tobergte, D.R., Curtis, S., 2013. Konica minolta. J. Chem. Inf. Model. 53 (9), 1689-1699.

United States Department of Agriculture-Food Safety and Inspection Service (USDA-FSIS), 1996. Pathogen Reduction; Hazard Analysis and Critical Control Point (HACCP) Systems. 61 Federal Register.

Wenham, L.M., Locker, R.H., 1976. The effect of marinading on beef. J. Sci. Food Agric. 27 (12), 1079-1084. Available at: http://dx.doi.org/10.1002/jsfa.2740271202.

Wesceie, A.M., Joshua, B.G., Bradley, P.M., Elliot, T.R., 2009. Stress, sublethal injury, resuscitation, and virulence of bacterial foodborne pathogens. J. Food Prot. 72 (5), 1121-1138.

Whyte, P., McGill, K., Cowley, D., Madden, R.H., Moran, L., Scates, P., Carroll, C., O'Leary, A., Fanning, S., Collins, J.D., McNamara, E., Moore, J.E., Cormican, M., 2004. Occurrence of Campylobacter in retail foods in Ireland. Int. J. Food Microbiol. 95 (2), 111-118.

World Health Organizition (WHO), 2015. WHO|WHO's First Ever Global Estimates of Foodborne Diseases Find Children Under 5 Account for Almost One Third of Deaths. pp. 1-5. Retrieved from. http://www.who.int/mediacentre/news/releases/2015/ foodborne-disease-estimates/en/\#.

Wu, V.C.H., 2008. A review of microbial injury and recovery methods in food. Food Microbiol. 25 (6), 735-744.

Yang, X., He, A., Badoni, M., Tran, F., Wang, H., 2016. Mapping sources of contamination of Escherichia coli on beef in the fabrication facility of a commercial beef packing plant. Food Control 1-7. Available at: http://linkinghub.elsevier.com/retrieve/pii/ S0956713516306776. 